\title{
Protocol optimization and histological analysis of in vitro plant regeneration of 'RB92579' and 'RB93509' sugarcane cultivars
}

\author{
Otimização do protocolo e análise histológica da regeneração in vitro de plantas dos cultivares de cana- \\ de-açúcar 'RB92579' e 'RB93509'
}

\author{
Roberson Dibax ${ }^{\mathrm{I}}$ Giovana Bomfim de Alcantara ${ }^{\mathrm{II}}$ Marília Pereira Machado ${ }^{\mathrm{II}}$ \\ João Carlos Bespalhok Filho ${ }^{\mathrm{III}}$ Ricardo Augusto de Oliveira ${ }^{\mathrm{III}}$
}

\begin{abstract}
The objectives of this study were to establish appropriate conditions for obtaining plant regeneration and acclimatization of the 'RB92579' and 'RB93509' sugarcane cultivars and to elucidate the shoots origin through histological analysis. For both cultivars, obtaining shoots showed better results with the culture of explants on a callus induction medium containing 2.0mg $L^{-1}$ 2,4-dichlorophenoxyacetic acid, followed by cultivation on a shoot induction medium containing $0.1 \mathrm{mg}$ $L^{-1}$ kinetin and $0.2 \mathrm{mg} \mathrm{L}^{-1}$ benzilaminopurine. The MS medium without growth regulators proved to be appropriate for elongation and rooting of shoots and the use of the composed substrate of vermiculite $+M S$ salts was effective for acclimatization. Histological analysis revealed that the origin of the shoots in both cultivars occurred through indirect organogenesis.
\end{abstract}

Key words: 2,4-dichlorophenoxyacetic acid, organogenesis, tissue culture, acclimatization. Poaceae.

\section{RESUMO}

Os objetivos deste estudo foram estabelecer condições apropriadas para a obtenção de regeneração de plantas e aclimatização das cultivares 'RB92579' e 'RB93509' de cana-de-açúcar e elucidar a origem das brotações através da análise histológica. Em ambas as cultivares, as brotações obtidas apresentaram os melhores resultados com a cultura dos explantes em um meio de indução de calo contendo 2,0mg $L^{-1}$ de ácido 2,4-diclorofenoxiacético, seguido do cultivo em meio indutor de brotações, contendo $0,1 \mathrm{mg}^{-1}$ de cinetina e $0,2 \mathrm{mg} \mathrm{L}^{-1}$ benzilaminopurina. $O$ meio $\mathrm{MS}$ sem reguladores de crescimento foi adequado para o alongamento e enraizamento das brotações e da utilização do substrato composto de vermiculite + sais do meio MS, foi eficaz para a aclimatização.
A análise histológica revelou que a origem das brotações em ambas as cultivares ocorreu via organogênese indireta.

Palavras-chave: ácido 2,4-diclorofenoxiacético, organogênese, cultura de tecidos, aclimatização, Poaceae.

\section{INTRODUCTION}

The sugarcane crop stands out in the world mainly because it is a renewable energy source for producing ethanol and contributing to produce $65 \%$ of world sugar. In Brazil, the sugarcane cultivation is installed in an area of more than eight million hectares, producing over 624 million tons of sugarcane, according to the 2010/2011 crop forecasting. Brazil is the world leader in the use of sugarcane as a source of renewable energy and sugar exports (CONAB, 2011). The RB92579 and RB93509 occupy a prominent status in the productive sector of the Northeast region of Brazil due to high potential for tolerance to drought and herbicides, good tillering rate and high agricultural productivity (BARBOSA et al., 2007). In vitro organogenesis is a fundamental step for obtaining genetically transformed plants and no information about the regeneration protocols for 'RB92579' and 'RB93509' sugarcane cultivars are found in the literature due to in vitro recalcitrance for somatic embryogenesis induction for these cultivars. In this sense, efficient protocols for in vitro regeneration should be

IUniversidade Federal da Fronteira Sul (UFFS), Laranjeiras, PR, Brasil. E-mail: roberson.dibax@uffs.edu.br. *Autor para correspondência. "Programa de Pós-Graduação em Agronomia - Produção Vegetal, Universidade Federal do Paraná (UFPR), Curitiba, PR, Brasil.

IIIDepartamento de Fitotecnia e Fitossanitarismo, UFPR, Curitiba, PR, Brasil. 
established for these cultivars. As the morphogenic response is influenced by genotype, it is essential to adapt the protocols performed for each cultivar. In vitro cultivation of sugarcane has been described for various cultivars through callus culture, meristems and somatic embryos (SRINIVASAN \& VASIL, 1986; HENDRE et al., 1993). The somatic embryogenesis induction has been obtained from explants of sugarcane inoculated in medium supplemented with various auxin types (HO \& VASIL, 1983; FITCH \& MOORE, 1990;BRISIBE et al., 1994). In other study, TAYLOR et al. (1992) described the induction of organogenic and embryogenic callus in 18 cultivars, as well as to obtain cell cultures in suspension. Plant regeneration from embryogenic callus obtained from immature leaves was observed by DIBAX et al. (2011), NIEVES et al. (2008), VICKERS et al. (2005) and BLANCO et al. (1997) and using MS medium (MURASHIGE \& SKOOG, 1962) supplemented with 2,4 dichlorophenoxyacetic acid (2,4-D) and LIU (1993), using different combinations of 2,4-D, kinetin (KIN), benzylaminopurine (BAP) and calcium pantothenate. For in vitro plant regeneration it is necessary to carry out histological analyses to determine the route of regeneration in order to discover whether the origins of the plant are in somatic embryogenesis or organogenesis, and to determine whether or not this is a reliable technique for use in the genetic transformation of sugarcane.

The objectives of this study were to establish appropriate conditions for obtaining plant regeneration and acclimatization of the RB92579 and RB93509 sugarcane cultivars and to elucidate the shoots origin through histological analysis.

\section{MATERIAL AND METHODS}

\section{In vitro culture conditions}

All the cultures were maintained in a growth chamber under cold white fluorescent light, with a photon flux density of $60 \mu \mathrm{mol} \mathrm{m}^{-2} \mathrm{~s}^{-1}, 12 / 12$ light/dark regime and $25 \pm 2^{\circ} \mathrm{C}$. The cultures were performed in Petri dishes $(10 \mathrm{~cm}$ diameter and $2 \mathrm{~cm}$ height), containing $25 \mathrm{~mL}$ of MS basic medium and sealed with PVC film, or in glass flasks ( $6 \mathrm{~cm}$ diameter and 9 height) containing $40 \mathrm{~mL}$ of MS basic medium each and sealed with rigid polypropylene caps. All media had the $\mathrm{pH}$ adjusted to 5.8 and were autoclaved for $20 \mathrm{~min}$ at $120^{\circ} \mathrm{C}$.

Callus and shoot induction and plant acclimatization Young meristematic leaf-rolls of sugarcane (Saccharum spp.) 'RB92579' and 'RB93509' cultivars were used as explants. The explants were collected from 2-month-old plants originated through vegetative propagation and cultured under greenhouse conditions. The explants were surface-sterilized by immersion in $70 \%$ alcohol $(\mathrm{v} / \mathrm{v})$ for $2 \mathrm{~min}$ and then in a $2 \%$ sodium hypochlorite (v/v) for 30min. They were subsequently rinsed three times in sterile distilled water and cut into sections of about $50 \mathrm{~mm}$ and immersed for $30 \mathrm{~min}$ in antioxidant solution composed of $250 \mathrm{mg} \mathrm{L}^{-1}$ of ascorbic acid, $25 \mathrm{mg} \mathrm{L}^{-1}$ citric acid and $1.0 \mathrm{~g} \mathrm{~L}^{-1} \mathrm{PVP}$ and $\mathrm{pH}$ adjusted to 5.0 (TOURNIER et al., 2003). The explants were isolated in Petri dishes containing the callus induction medium (CI medium) composed of MS medium, $30 \mathrm{~g} \mathrm{~L}^{-1}$ sucrose, $7 \mathrm{~g} \mathrm{~L}^{-1}$ agar, $500 \mathrm{mg} \mathrm{L}^{-1}$ of PVP, $500 \mathrm{mg} \mathrm{L}^{-1}$ of hydrolyzed casein and supplemented with 2,4-D at concentrations of $0,1,2$ and $3 \mathrm{mg} \mathrm{L}^{-1}$. After $30 \mathrm{~d}$ of culture in the dark in the growth room, the percentages of explants forming callus and necrosis of callus were evaluated.

The experimental design was totally randomized, $2 \times 3$ (two cultivars $\mathrm{x}$ three 2,4-D concentrations) factorial scheme with 5 replicates per treatment and 8 explants per flask. The results were submitted to regression analysis using the MSTAT$\mathrm{C}^{\mathrm{TM}}$ program version 2.10 (Russell D. Freed, Mstate Director, Crop and Soil Science Department, Michigan State University, USA).

The callus obtained in callus induction medium (CI) with $2 \mathrm{mg} \mathrm{L}^{-1}$ 2,4-D were divided into slices of $3 \mathrm{~mm}$ and transferred to shoot induction medium (SI) composed of MS medium with $0.1 \mathrm{mg} \mathrm{L}^{-1} \mathrm{KIN}, 0.2 \mathrm{mg} \mathrm{L}^{-1}$ BAP, 250 $\mathrm{mg} \mathrm{L}^{-1} \mathrm{PVP}$ and incubated for 15 days in the dark in the growth room and after that for 15 days in an additional period of culture in light condition. Ten Petri dishes containing 10 clusters of callus were used, totaling 100 callus per cultivar. After $30 \mathrm{~d}$ of culture, the percentage of callus forming shoots and average number of shoots per sample were evaluated. Shoots obtained in the previous experiments were transferred to MS medium without growth regulators for $60 \mathrm{~d}$ to promote the elongation and rooting of plants. The plantlets were transferred to substrate composed by vermiculite + MS salts and kept in greenhouse without temperature control under intermittent mist and covered with Sombrite ${ }^{\circledR}$ (50\% PDF reduction). Thirty days after the initial culture period, percentage of surviving plants was evaluated.

Histological analysis

Five samples were collected at day 15,30 after the explant inoculation on a CI medium with $2.0 \mathrm{mg}$ $\mathrm{L}^{-1}$ 2,4-D and after transference to SI medium with $0.1 \mathrm{mg}$ $\mathrm{L}^{-1} \mathrm{KIN}$ and $0.2 \mathrm{mg} \mathrm{L}^{-1} \mathrm{BAP}$. The samples were fixed in formaldehyde/acetic acid/alcohol (FAA) 70\% (v/v) under vacuum for $24 \mathrm{~h}$, in accordance with JOHANSEN 
(1940) protocol. After that the material was transferred into $70 \%(\mathrm{v} / \mathrm{v})$ ethanol and dehydrated in an ethanol series. The samples were then embedded in glycol methacrylate (GMA) following the procedure described by FEDER \& O'BRIEN (1968) and the manufacturer's instructions (JB4 - PolyScience ${ }^{\circledR}$ ). After the inclusion, longitudinal sections were made with a rotary microtome with steel razor type $\mathrm{C}$, giving a thickness of $7.0 \mathrm{~mm}$.

\section{RESULTS AND DISCUSSION}

Callus and shoots induction and plant acclimatization Regarding to the percentage of callus induction, the regression equations indicated optimum value of $1.6 \mathrm{mg} \mathrm{L}^{-1} 2.4-\mathrm{D}$ for both cultivars with rates of $21.08 \%$ for 'RB92579' and $19.10 \%$ for 'RB93509' (Figure 1A). Different results were found by ATHER et al., (2009) when studied the callus induction from meristematic explants of sugarcane cv. Thatta-10. For these authors, $100 \%$ of callus induction were reported with the utilization of $3.0 \mathrm{mg} \mathrm{L}^{-1}$ of 2,4-D. The mucilaginous callus induction began $15 \mathrm{~d}$ after isolation and was originated from the central section of explants. Thirty days after isolation it was possible to observe the small clusters formation of nodular structures similar to globular embryos from mucilaginous callus. In studies with other sugarcane cultivars, GARCIA et al. (2007) and LIMA et al. (2001) also observed the callus induction on MS media containing 2.4-D with the same morphological characteristics described here. With regard to the percentage of necrotic callus, the regression equations indicated optimum value of $1.6 \mathrm{mg} \mathrm{L}^{-1} 2.4-\mathrm{D}$ for both cultivars with rates of $78.93 \%$ for 'RB92579' and $81.50 \%$ for RB93509. Thirty days after the callus isolation it was observed shoot induction from callus in $91 \%$ of RB92579 cultivar and 60\% for the 'RB93509' cultivar.
The present results confirmed the BAP and KIN effect in the shoot regeneration of sugarcane described by ALI et al. (2008). These authors reported that the shoot regeneration from nodular callus was $60 \%$ with the use of $0.26 \mathrm{mg} \mathrm{L}^{-1} \mathrm{KIN}$ and $0.25 \mathrm{mg} \mathrm{L}^{-1}$ BAP. In another study, ATHER et al. (2009) reported that the addition of $1.0 \mathrm{mg}$ $\mathrm{L}^{-1} \mathrm{BAP}$ into the MS medium provided a $31.5 \%$ rate of shoot induction from nodular callus after 4 weeks of culture. The MS medium without growth regulators promoted the shoot elongation and rooting in more then $90 \%$ of both cultivars after 30 days of isolation. Regarding to plant acclimatization, the averages for the plant survival percentage revealed was $75 \%$ for both cultivars. Sugarcane acclimatization of in vitro regenerated plants can be achieved successfully if the plants are initially cultured with high humidity conditions as demonstrated by SNYMAM et al. (2006) and SENGAR et al. (2009). These authors easily acclimatized sugarcane plants using soil as substrate and initial plants culture in mist chamber condition and plant fertilization weekly.

\section{Histological analysis}

The transversal section of the sugarcane explants showed the induction of nodular callus accompanied by external areas with intense cell division after 30 days of culture on a CI medium containing 2,4-D. According to the observed results, the shoot regeneration of 'RB92579' cultivar had been induced from two distinct types of cellular organizations. At first, the shoots were induced after 30 days of culture in SI medium containing $0.1 \mathrm{mg} \mathrm{L}^{-1}$ $\mathrm{KIN}$ and $0.2 \mathrm{mg} \mathrm{L}^{-1} \mathrm{BAP}$ from nodular callus (Figure 2A). Fifteen days after the callus isolation on a SI medium, it was possible to observe in a sample of 'RB93509' cultivar the connection of shoot meristems with procambium tissues (Figure 2B). In some explants
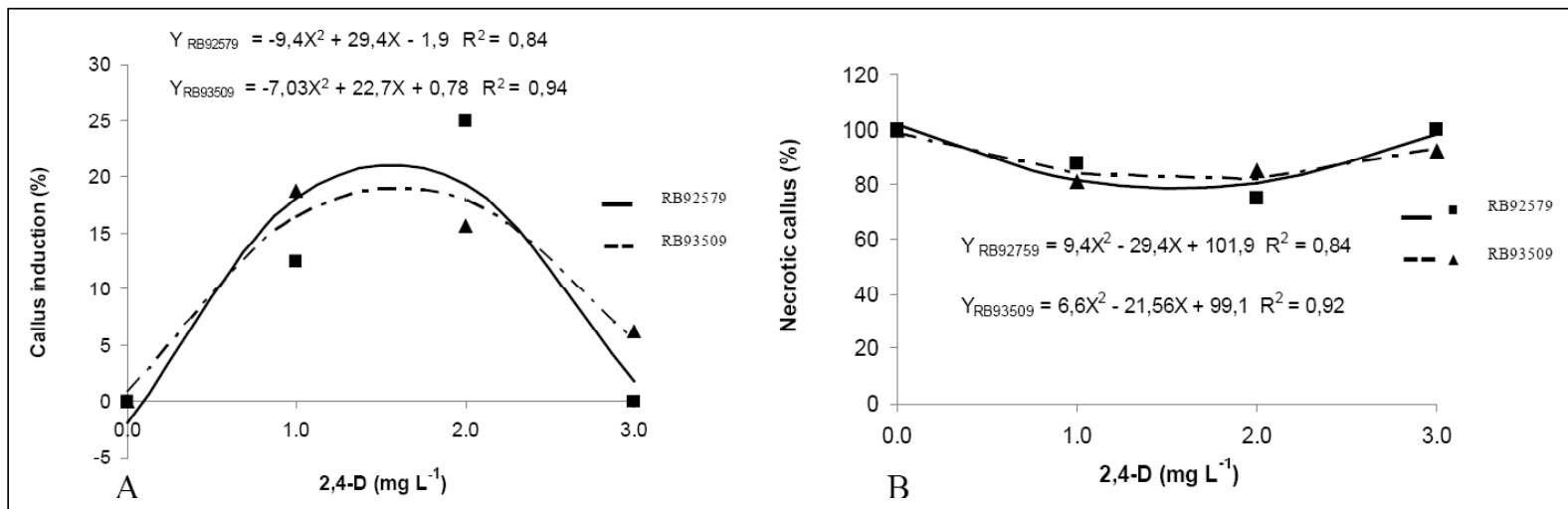

Figure 1 - 2,4-D effect on callus induction of 'RB92579' and 'RB93509' cultivars after 30d of culture period on MS medium (A) Percentage of callus induction (B) Percentage of necrotic callus. 


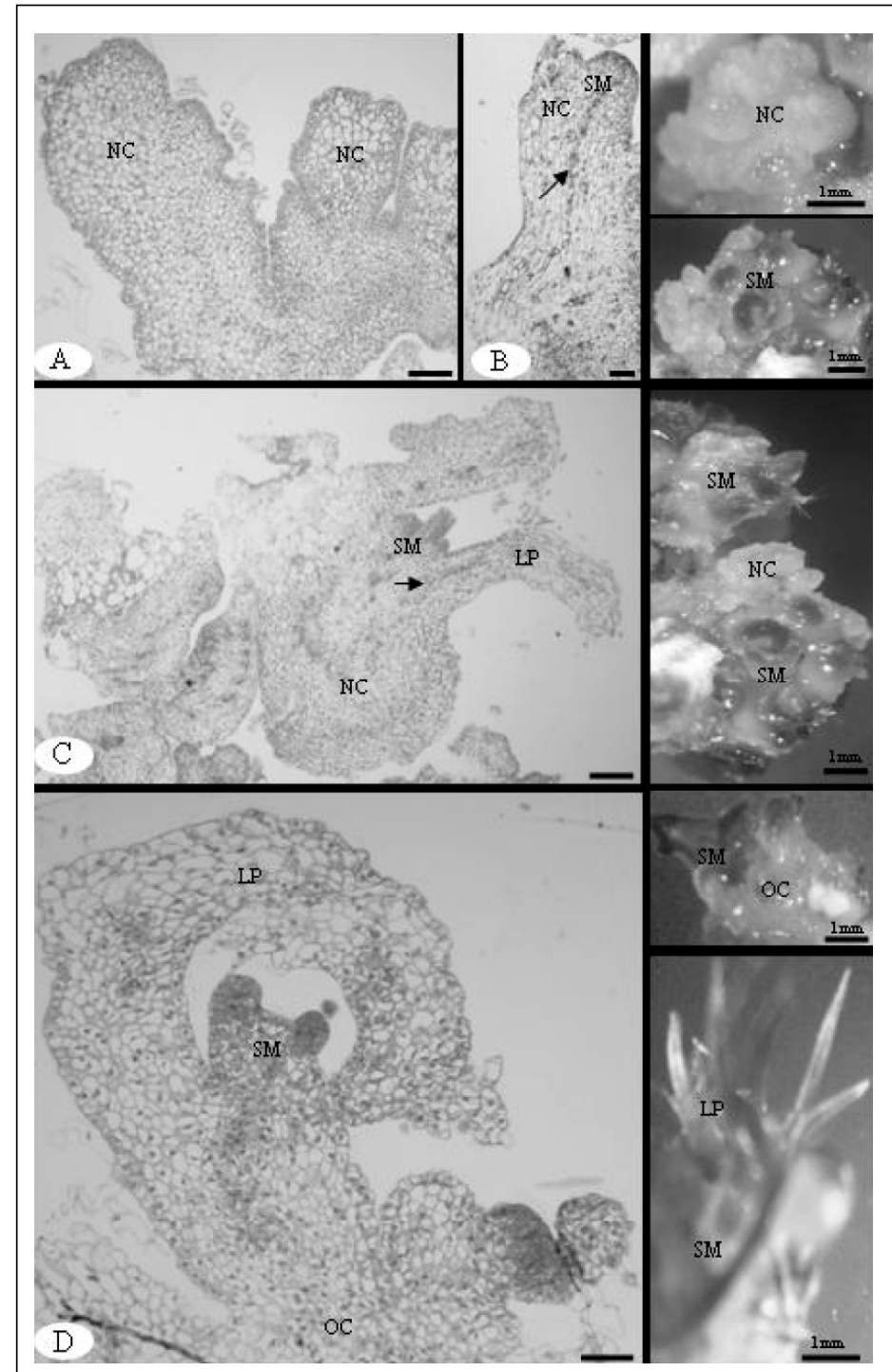

Figure 2 - Histological study of callus and shoots induction from explants of 'RB92579' and 'RB93509' sugarcane cultivars at different stages of cell differentiation. (A) Explants of RB92579 sugarcane cultivar showing nodular callus induction and external areas with intense cell division after 15 days of culture on medium (IC) containing $2.0 \mathrm{mg} \mathrm{L}^{-1}$ 2.4-D. (B) Shoot meristem in RB93509 sugarcane showing connection with the procambium tissues (arrow) after 15 days of cultivation on IB medium. (C) Detail of shoot meristem induced from nodular callus and leaves primordium of 'RB92579' sugarcane cultivar after 30 days of culture on (IB) medium. (D) Shoot meristems induction from organogenic callus of 'RB92579' sugarcane cultivar after 30 days of culture on (IB) medium. Abbreviations: $(\mathrm{SM})=$ Shoot meristems, $(\mathrm{LP})=$ leaf primordium, $(\mathrm{NC})=$ nodular callus, $(\mathrm{S})=$ shoots,$(\mathrm{OC})=$ organogenic callus. Bars: $(8=300 \mu \mathrm{m} ; 9=100 \mu \mathrm{m} ; 10=200 \mu \mathrm{m} ; 10=300 \mu \mathrm{m})$.

of 'RB92579' cultivar was possible to observe the shoot meristems induced from nodular callus and leaves primordium formation (Figure 2C). Regarding the results described in the literature and here observed the morphological variations of callus and shoot regeneration pathways are frequently reported in studies of in vitro shoot induction of sugarcane. The association of organogenic and embryogenic callus 
on the same sugarcane explant and the plant regeneration through indirect organogenesis from friable callus has been described in some studies (GNANAPRAGASAM \& VASIL, 1992; TAYLOR et al., 1992; RODRIGUEZ et al., 1995). In another study, FRANKLIN et al. (2006) reported the shoots induction of sugarcane from globular structures associated with the original explant and suggest that somatic embryos in globular stage may lead shoots induction from indirect organogenesis in the presence of cytokines, confirming the results observed here. The induction of shoots obtained in this study can be explained by the fact that the callus of 'RB92579' and 'RB93509' cultivars has been obtained after 30 days of culture on SI medium with 2,4-D, a culture period relatively short to complete the somatic embryos formation in sugarcane. After the explants transference to MS medium containing cytokinins, a pathway redirection had been induced the shoot regeneration from nodular callus similar to somatic embryos in globular stage. The same results were described by FALCO et al. (1996). These author observed nodular callus of sugarcane SP70-1143 cultivar were induced on MS medium containing 2,4-D in which has been accompanied by external areas with intense cell division similar to caulinar apical meristems. These authors reported that the shoot meristem has been surrounded by leaf primordium and the serial sections confirmed the unipolar nature of the structures and their connections with the callus tissues indicating that the shoots regeneration occurred through the indirect organogenesis. In the second type of cell organization that regenerated shoots, the shoot meristems has been originated directly from callus induced in some samples of 'RB92579' cultivar with organogenic aspect, watery and translucent (Figure 2D). Similary, GARCIAet al. (2007) observed that shoots of 'RB758540' sugarcane cultivar were originated from callus cultured on MS medium containing $1.0 \mathrm{mg} \mathrm{L}^{-1}$ of picloram after 30 days of isolation in light conditions. FALCO et al. (1996) observed the shoot regeneration of sugarcane through indirect organogenesis in explants cultured on MS medium containing $1.0 \mathrm{mg} \mathrm{L}^{-1}$ BAP. According to the results, it was proved that the shoots regeneration of 'RB92579' and 'RB93509' sugarcane cultivars occurred through the indirect organogenesis

\section{CONCLUSION}

The explants cultured in the conditions described here originated adventitious shoots and acclimatized plants were obtained. Histological analysis revealed that the origin of adventitious shoots occurred from two types of cellular organizations (nodular callus similar to somatic embryos in globular stage and organogenic callus, translucent and friable). In both of cases the shoot regeneration in 'RB92579' and 'RB93509' sugarcane cultivars occurred through the indirect organogenesis and due to it the information described here may be used to the production of sugarcane plants through genetic transformation.

\section{ACKNOWLEDGEMENTS}

The authors would like to thank the CNPq and FAPITEC for financial support, the Laboratóriode Cultura de Tecidos, Departamento de Engenharia Agronômica, Universidade Federal de Sergipe and the Laboratório de Botânica Estrutural, Departamento de Botânica, Universidade Federal do Paraná by the availability of necessary infrastructure for this study.

\section{REFERENCES}

ALI, A. et al. Rapid clonal multiplication of sugarcane (Saccharum officinarum) through callogenesis and organogenesis. Pakistan Journal of Botany, v.40, n.01, p.123-138, 2008. Available from: <http://www.pakbs.org/pjbot/ PDFs/40(1)/PJB40(1)123.pdf>. Accessed: nov. 20, 2011.

ATHER, A. et al. Optimization of the protocols for callus induction, regeneration and acclimatization of sugarcane cv. thatta-10. Pakistan Journal of Botany, 41, p.815-820, 2009. Available from: <http://.fao.org/agrissearch/search/ display.do?f=2011/PK/PK1112.xml;PK2011001173>. Accessed: nov. 15, 2011.

BARBOSA, G.V.S. et al. Relatório Técnico Safra 2006-2007. Programa de Melhoramento Genético de Cana-de-Açúcar. Rio Largo, AL. Maio, 2007. (Boletim Técnico).

BLANCO, M.A. et al. Protein changes associated with plant regeneration in embryogenic calli of sugarcane (Saccharum sp.). Plant Cell, Tissue and Organ Culture, v.51, p.153158, 1997. Available from: <http://www.springerlink.com/ content/m821672wx472511k/>. Acessed: jan.15, 2011. doi: 10.1023/A: 1005963925773 .

BRISIBE, E.A. et al. Regulation of somatic embryogenesis in long-terms callus cultures of sugarcane (Saccharum officinarum L.). New Phytologist, v.126, p.301-307, 1994. Available from: <ht tp://onlinelibrary.wiley.com/doi/ $10.1111 /$ j.14698137.1994.tb03949.x/abstract>. Acessed: jan. 30, 2011. doi: 10.1111/j.1469-8137.1994.tb03949.x.

CONAB (COMPANHIA NACIONAL DE ABASTECIMENTO). Central de informações agropecuárias: safras - cana. 2007. Available from: <http://www.conab.gov.br>. Acessed: jan.15, 2011.

DIBAX, R. et al. Plant regeneration of sugarcane cv. RB931003 and RB98710 from somatic embryos and acclimatization. Journal of Biotechnology and Biodiversity, v.2, p.32-37, 2011. Available from: <http://revista.uft.edu.br/index.php/JBB/ article/viewArticle/119>. Acessed: fev.2, 2012. 
FALCO, M.C. et al. Histological characterization of in vitro regeneration of Saccharum sp. Revista Brasileira de Fisiologia Vegetal, v.08, n.02, p.93-97, 1996. Available from: < h t t p : / / s c h o l a r.goog 1 e.co m. b r / scholar?q=FALCO,+ M. + C. + et + al + Histological $+c$ haracterization + of $\&$ h $1=p t B R \&$ a s $\_s d t=0 \&$ as vis $=1 \&$ oi $=$ scholart \&sa $=X \&$ ei $=s 4$ p 5 T 4 C KJ Y L 50 g GstMiyDQ\&sqi=2\&ved=0CBoQgQMwAA>. Acessed: may. 10, 2009.

FEDER, N.; O'BRIEN, T.P. Plant microtechnique: some principles and new methods. American Journal of Botany, v.5, p.123-142, 1968. Available from: <http://www.jstor.org/ discover $/ 10.2307 / 2440500$ ? uid $=3737664 \&$ uid $=2129 \&$ uid $=2$ \&uid $=70 \&$ uid $=4 \&$ sid $=47698831481497>$. Acessed: may. 10, 2009.

FITCH, M.M.M.; MOORE, P.H. Comparison of 2,4-D and picloram for selection of long-term totipotent green callus of sugarcane. Plant Cell, Tissue and Organ Culture, v.20,p.157-163, 1990. Available from: <http:// www.springerlink.com/content/p33p1g11g5133682/>. Acessed: fev. 3, 2012. doi: 10.1007/BF00041876.

FRANKLIN, G. et al. Auxin pretreatment promotes regeneration of sugarcane (Saccharum spp. hybrids) midrib segment explants. Plant Growth Regulation, v.50, p.111119, 2006. Available from: <http://www.springerlink.com/ content/13m78t1458310132/>. Acessed: 05 fev. 5, 2012. doi: $10.1007 / \mathrm{s} 10725-006-9108-4$.

GARCIA, R. et al. In vitro morphogenesis patterns from shoot apices of sugar cane are determined by light and type of growth regulator. Plant Cell, Tissue and Organ Culture, v.90, p.181-190, 2007. Avalaible from: <http://www.deepdyve.com/ lp/springer-journals/in-vitro-morphogenesis-patterns-fromshoot-apices-of-sugar-cane-are-4uQbCgZZWz>. Acessed: fev.10, 2012. doi: 10.1007/s11240-007-9235-2.

GNANAPRAGASAM, S.; VASIL, I.K. Cryopreservation of immature embryos, embryogenic callus and cell suspension cultures of gramineous species. Plant Science, v.83, p.205215, 1992. Available from: <http://dx.doi.org/10.1016/01689452(92)90080-6>. Acessed: fev. 12, 2012. doi: 10.1016/ 0168-9452(92)90080-6.

HENDRE, R. et al. Differences in repeated DNA sequences between callus and shoot tissue of sugarcane (Saccharum officinarum L.). Indian Journal of Biochemistry \& Biophysics, v.23, p.80-86, 1993.

HO, J.; VASIL, I.K. Somatic embryogenesis in sugarcane (Saccharum officinarum). The morphology and physiology of callus formation and the ontogeny somatic embryos. Protoplasma, v.118, p.169-180, 1983. Available from: <http:/ /www.springerlink.com/content/1525955186517140>. Acessed: jan. 12, 2012. doi: 10.1007/BF01281800.

JOHANSEN, D.A. Plant microtechnique. New York: Mac Graw Hill Book, 1940. 523p.
LIMA, M.A.C. et al. In vitro morphogenesis of Brazilian sugarcane (Saccharum officinarum $\mathrm{L}$.) varieties and callus susceptibility to selective markers used in genetic transformation systems. Revista Brasileira de Botânica, v.24, p.73-77, 2001. Available from: <http://www.scielo.br/ scielo.php?script=sci_arttext $\&$ pid=S010084042001000100008 $>$. Acessed: dez.10, 2011. doi: 10.1590/S0100-84042001000100008.

LIU, M.C. Factors affecting induction, somatic embryogenesis and plant regeneration of callus from cultured immature inflorescence of sugarcane. Journal of Plant Physiology, v.141, p.714-720, 1993. Available from: <http://www.sciencedirect.com/ science/article/pii/S0176161711815804>. Acessed: set. 9, 2009.

MURASHIGE, T.; SKOOG, F. A revised medium for rapid growth and bioassays with tobacco tissue cultures. Physiologia Plantarum, v.15, p.473-497, 1962. Available from: <http:// garfield.library.upenn.edu/classics1978/A1978FR51700002.pdf>. Acessed: abr. 10, 2009.

NIEVES, F. et al. Effect of exogenous arginine on sugarcane (Saccharum sp.) somatic embryogenesis, free polyamines and the contents of the soluble proteins and proline. Plant Cell, Tissue and Organ Culture, v.95, p.313-320, 2008. Available from: <http://www.springerlink.com/content/487606290708444w/>. Acessed: mar. 15, 2010.

RODRIGUEZ, S. et al. Sugarcane somatic embryogenesis: a scanning electron microscopy study. Tissue Cell, v.28, n.2, p.149-154, 1995. Available from: <http://www.sciencedirect.com/ science/article/pii/S0040816696800036>. Acessed: ago. 12, 2011.

SRINIVASAN, C.; VASIL, I. Plant regeneration from protoplasts of sugarcane (Saccharum officinarum L.). Plant Physiology, v.126, p.41-48, 1986. Available from: <http:// www.sciencedirect.com/science/article/pi / S0176161786802140>. Acessed: mar.10, 2012. doi: 10.1016/ S0176-1617(86)80214-0.

SENGAR, A.S. et al. In vitro selection at cellular level for red rot resistance in sugarcane (Saccharum sp.). Plant Growth Regulation, v.58, p.201-209, 2009. Available from: <http:// www.springerlink.com/content/347052np75k1 g762/>. Acessed: set. 18, 2011. doi: 10.1007/s10725-009-9368-x.

TAYLOR, P.W.J. et al. Establishment of embryogenic callus and high protoplast yielding suspension cultures of sugarcane (Saccharum spp. hybrids). Plant Cell, Tissue and Organ Culture, v.28, p.69-78, 1992. Available from: <http:// www.springerlink.com/content/t5651w7w56214v37/>. Acessed: abr. 16, 2012.

TOURNIER, V. et al. An efficient procedure to stably introduce genes into an economically important pulp tree (Eucalyptus grandis x Eucalyptus urophylla). Transgenic Research, v.12, p.403-411, 2003.

VICKERS, J.E. et al. Tissue culture and biolistic transformation of callus have independent effects on yield and sugar content of transgenic sugarcane in the field. Australian Journal of Agricultural Research, v.56, p.57-68, 2005. 